\title{
APLIKASI TEKNOLOGI PENGOLAHAN AIR LIMBAH DOMESTIK MENGGUNAKAN KOMBINASI BIOFILTER AEROBIK MEDIA PLASTIK SARANG TAWON DAN BIOFILTER MEDIA KERIKIL DENGAN ALIRAN KE ATAS
}

\author{
Khalidah Nurul Azmi ${ }^{1}$, Irma Gusniani Danumihardja ${ }^{1}$, Nusa Idaman Said ${ }^{2}$ \\ ${ }^{1}$ Departemen Teknik Sipil, Fakultas Teknik, Universitas Indonesia, Depok, 164262, Indonesia \\ ${ }^{2}$ Pusat Teknologi Lingkungan, BPPT, Kawasan Puspiptek, Tangerang Selatan, 15314, Indonesia \\ E-mail: amirazaq@gmail.com ; nusaidamansaid@gmail.com
}

\begin{abstract}
ABSTRAK
Air limbah domestik memberikan kontribusi besar terhadap pencemaran air di perkotaan karena penerapan pengolahannya belum optimal. Penelitian kombinasi biofilter aerobik dengan media plastik sarang tawon (MPST) dan media kerikil (MK) dilakukan untuk mengolah air limbah domestik. Pemilihan proses mempertimbangkan baku mutu dan sasaran penerapannya untuk skala individual. Kombinasi pada HRT 24 jam menurunkan COD, NH4-N, TSS masing-masing 84,09\%, 81,62\%, 93,9\%. Pada HRT 36 jam, menurunkan COD, NH4-N, TSS masing-masing 76,68\%, 97,67\%, 85,04\%. Efisiensi dipengaruhi oleh variasi HRT dan perlakuan pada HRT 24 jam untuk meningkatkan kinerja reaktor, yaitu perubahan HRR dan tipe aerasi. Perubahan HRR dari 1 ke 0,25 (aerasi samping) meningkatkan kinerja reaktor dalam menurunkan COD dari $81,5 \%$ menjadi $88,05 \%$, NH4-N dari $77,23 \%$ menjadi $81,7 \%$, TSS dari 93,43\% menjadi $96,35 \%$. Perubahan tipe aerasi dari aerasi samping menjadi aerasi merata (HRR 0,25) meningkatkan kinerja reaktor dalam menurunkan $\mathrm{NH} 4-\mathrm{N}$ dari $81,7 \%$ menjadi $89,56 \%$, sementara COD turun dari $88,05 \%$ menjadi $82,22 \%$ dan TSS turun dari $96,35 \%$ menjadi $90,66 \%$. HRT 36 jam dipilih sebagai HRT optimum dengan aerasi merata dan HRR 0,25. Hal ini terkait efisiensi penurunan $\mathrm{NH}_{4}-\mathrm{N}$ yang sangat tinggi karena DO $>2 \mathrm{mg} / \mathrm{L}$ dengan aerasi merata dan dalam HRT yang lebih lama, serta semua parameter berada di bawah baku mutu.
\end{abstract}

Kata kunci: air limbah domestik; biofilter aerobik; efisiensi penurunan; HRT

\section{APPLICATION OF DOMESTIC WASTEWATER TREATMENT TECHNOLOGY USING COMBINATION OF UPFLOW AEROBIC HONEYCOMB PLASTIC MEDIA BIOFILTER AND GRAVEL MEDIA BIOFILTER}

\author{
Khalidah Nurul Azmi ${ }^{1}$, Irma Gusniani Danumihardja1 ${ }^{1}$, Nusa Idaman Said ${ }^{2}$ \\ ${ }^{1}$ Civil Engineering Department, Faculty of Engineering, University of Indonesia, Depok, 164262, Indonesia \\ ${ }^{2}$ Center for Environmental Technology, BPPT, Puspiptek Area, South Tangerang, 15314, Indonesia \\ E-mail: amirazaq@gmail.com ; nusaidamansaid@gmail.com
}

\begin{abstract}
Domestic wastewater contributes greatly to water pollution in urban because application of treatment has not been optimal. Research of aerobic biofilter combination with honeycomb plastic media (MPST) and gravel media (MK) to treat domestic wastewater was done. Selection of process considered effluent standard and implementation for individual scale. Combination in HRT 24 hours reduced COD, NH4-N, TSS by $84,09 \%, 81,62 \%, 93,9 \%$, respectively. In HRT 36 hours, reduced COD, NH4-N, TSS by 76,68\%, $97,67 \%, 85,04 \%$, respectively. Removal efficiencies were influenced by HRT variation and some treatments in HRT 24 hours to improve reactor performance, i.e. HRR and aeration type changes. HRR change from 1 to 0,25 (side aeration) improved reactor performance in reducing COD from 81,5\% to $88,05 \%$, NH4-N from $77,23 \%$ to $81,7 \%$, TSS from $93,43 \%$ to $96,35 \%$. Aeration type change from side aeration to fine aeration (HRR 0,25) increased reactor performance in reducing NH4-N from $81,7 \%$ to $89,56 \%$, while COD decreased from $88,05 \%$ to $82,22 \%$ and TSS decreased from $96,35 \%$ to $90,66 \%$. HRT 36 hours was selected as optimum HRT with fine aeration and HRR 0,25. This considered highly removal efficiency of $\mathrm{NH} 4-\mathrm{N}$ due to $\mathrm{DO}>2 \mathrm{mg} / \mathrm{L}$ with fine aeration and longer $\mathrm{HRT}$, and all parameters below effluent standard.
\end{abstract}

Keywords : aerobic biofilter; domestic wastewater; HRT; removal efficiency 


\section{PENDAHULUAN}

Masalah utama dari air limbah adalah timbulannya dalam jumlah banyak dengan beban organik tinggi dan potensi pencemaran yang serius (Mishra et al., 2015). Untuk wilayah Jakarta, dari segi jumlah, air limbah domestik (rumah tangga) memberikan kontribusi terhadap pencemaran air sekitar 75\%, air limbah perkantoran dan daerah komersial $15 \%$, dan air limbah industri hanya sekitar 10\% (Said, 2017). Permasalahan yang ada hingga saat ini terkait air limbah domestik di Indonesia adalah laju perkembangan pembangunan sarana pengelolaan air limbah secara terpusat sangat lambat (hanya sekitar 3,5\% dari luas total daerah pelayanan), serta teknologi pengolahan air limbah rumah tangga individual (on site treatment), ataupun semi komunal yang ada tidak memadai atau sangat kurang sekali (Said, 2005). Sementara itu, Peraturan Menteri Lingkungan Hidup dan Kehutanan Republik Indonesia Nomor: $\quad$ P.68/Menlhk/Setjen/Kum.1/8/2016 tentang Baku Mutu Air Limbah Domestik yang berlaku saat ini sifatnya lebih ketat dimana kadar maksimum parameter yang ditetapkan antara lain BOD $30 \mathrm{mg} / \mathrm{L}$, COD $100 \mathrm{mg} / \mathrm{L}$, TSS $30 \mathrm{mg} / \mathrm{L}$, amoniak $10 \mathrm{mg} / \mathrm{L}$. Maka, diperlukan suatu teknologi pengolahan air limbah domestik di daerah perkotaan untuk memenuhi baku mutu air limbah domestik saat ini. Menurut Said \& Hartaja (2015), dalam menentukan teknologi pengolahan air limbah harus didasarkan kepada karakteristik air limbah yang akan diolah. Salah satu jenis teknologi pengolahan berdasarkan karakteristik air limbah ialah pengolahan air limbah secara biologis yang memanfaatkan mikroorganisme untuk menguraikan polutan tertentu. Pemilihan teknologi pengolahan air limbah domestik bagi skala individual dalam hal ini diharapkan yang mudah dan murah untuk diterapkan.

\section{TINJAUAN TEORITIS}

Said \& Ruliasih (2005) dalam jurnalnya mengatakan bahwa saat ini salah satu proses pengolahan air limbah yang banyak digunakan adalah proses biologis dengan biakan melekat. Biofilter aerobik pada dasarnya merupakan sistem biakan melekat yang dapat digunakan sebagai proses pengolahan air limbah (Hait \& Mazumder, 2009). Proses biofilter telah secara berangsur-angsur digunakan pada masyarakat kecil, mengingat mudah dikelola dan dapat menghilangkan material organik dan padatan tersuspensi secara bersamaan (Kim et al., 2008; Ji et al., 2014). Biofilter aerobik tercelup (SABs) diketahui memberikan retensi padatan lebih baik dibandingkan dengan reaktor lumpur aktif (Gálvez et al., 2009; Metcalf \& Eddy, 2003; Ferraz et al., 2014).
Berdasarkan Said (2017), pengolahan air limbah dengan sistem biakan melekat atau biofilm dilakukan dengan cara mengalirkan air limbah ke dalam reaktor yang diisi dengan media yang mempunyai luas permukaan yang besar dimana film mikrobiologis (biofilm) melekat di permukaan media tersebut. Zat organik dapat disisihkan secara biologis yang tergantung dari jumlah oksigen terlarut, jenis mikroorganisme, dan jumlah zat pengurai. Adanya $\mathrm{O}_{2}$ menyebabkan proses oksidasi aerob dapat berlangsung, bahan-bahan organik akan diubah menjadi produk-produk akhir yang relatif stabil dan sisanya akan disintesis menjadi mikroba baru. Secara umum, reaksinya sebagai berikut:

Senyawa organik $+\mathrm{O}_{2}$

$\stackrel{\text { mikroba }}{\longrightarrow} \mathrm{CO}_{2}+\mathrm{H}_{2} \mathrm{O}+$ Sel baru + Energi

Di dalam proses biofiltrasi, senyawa amoniak akan diubah menjadi nitrit, kemudian senyawa nitrit akan diubah menjadi nitrat. Secara keseluruhan proses nitrifikasi dapat dilihat dari persamaan berikut :

$\mathrm{NH}_{4}{ }^{+}+2 \mathrm{O}_{2} \rightarrow \mathrm{NO}_{3}{ }^{-}+2 \mathrm{H}^{+}+\mathrm{H}_{2} \mathrm{O}$

Untuk pengolahan air limbah, bahan pendukung harus memenuhi kriteria berikut: tidak larut, tidak dapat terurai, tidak beracun, tidak mencemari, ringan, fleksibilitas dalam berbagai bentuk, stabilitas mekanik dan kimia yang tinggi, difusivitas tinggi, cara imobilisasi yang sederhana, retensi biomassa tinggi, pelekatan minimal organisme lain dan sebaiknya biaya rendah (Leenen et al., 1996; Zacheus et al., 2000; Martins et al., 2013). Jika berdasarkan Said (2017), media terstruktur memiliki semua karakteristik yang ada pada media "ideal". Salah satu jenis media terstruktur yang sering digunakan adalah media plastik sarang tawon (MPST). Media biofilter yang digunakan diantaranya dapat juga berupa media kerikil (MK). Menurut Newton \& Wilson (2008), gravel mengurangi risiko clogging dan memperkenankan laju beban hidrolik yang lebih tinggi. Gravel memiliki luas permukaan besar dimana partikel dapat tertahan oleh pengendapan (mekanisme penghilangan utama) dan pelekatan (Boller 1993; Galvis, 1999; Sánchez et al., 2015), sehingga memfasilitasi operasi filter yang lama (Sánchez et al., 2015).

\section{METODE PENELITIAN}

Pengolahan air limbah domestik skala laboratorium dilakukan dengan mengombinasikan biofilter aerobik media berbeda yaitu media Palstik Sarang tawon (MPST) dan media kerikil (MK) dengan aliran ke 
atas. Air limbah dialirkan terlebih dahulu melalui biofilter MPST, kemudian melalui biofilter MK agar pengolahan dapat menghasilkan kualitas efluen lebih baik. Baku mutu acuan yaitu Peraturan Menteri Lingkungan Hidup dan Kehutanan Republik Indonesia Nomor: P.68/Menlhk/Setjen/Kum.1/8/2016 tentang Baku Mutu Air Limbah Domestik. Pemilihan aliran ke atas berdasarkan Said (2008) bahwa efisiensi penyaringan akan sangat besar karena dengan adanya biofilter up flow yakni penyaringan dengan sistem aliran dari bawah ke atas akan mengurangi kecepatan partikel yang terdapat pada air buangan dan partikel yang tidak terbawa aliran ke atas akan mengendapkan di dasar bak filter. Gambar 1 memperlihatkan desain reaktor skala laboratorium yang digunakan. Sistem aliran continuous didukung dengan adanya pompa sirkulasi. Suplai udara kedua reaktor berasal dari 1 unit blower. Reaktor didesain berbahan akrilik ketebalan $5 \mathrm{~mm}$. Pipa PVC diameter $1 / 2$ in digunakan sebagai peralatan pendukung. Pengambilan sampel dilakukan di tiga titik yaitu influen reaktor, efluen biofilter MPST, dan efluen biofilter MK. Tabel 1 merangkum parameter yang didapat dari ketiga titik sampling

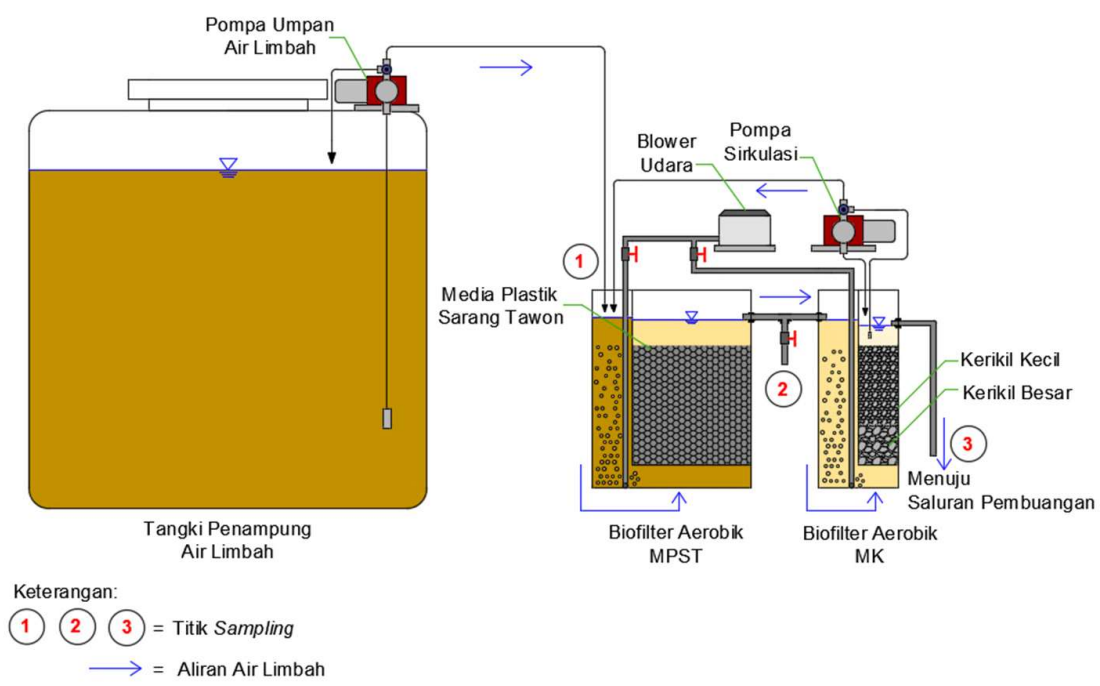

Gambar 1. Desain Reaktor Biofilter Aerobik Skala Laboratorium

Tabel 1. Pemerolehan Data di Titik Sampling

\begin{tabular}{c|c|c|c}
\hline \multirow{2}{*}{ Unit Proses } & \multicolumn{3}{|c}{ Titik Sampling } \\
\cline { 2 - 4 } Biofilter Aerobik MPST & $\begin{array}{c}\mathrm{COD}_{\text {inf, }} \mathrm{TSS}_{\text {inf, }} \\
\mathrm{NH}_{4}-\mathrm{N}_{\text {inf }}\end{array}$ & $\begin{array}{c}\mathrm{COD}_{\text {ef, }} \mathrm{TSS}_{\text {ef }} \\
\mathrm{NH}_{4}-\mathrm{N}_{\text {ef }}\end{array}$ \\
\hline Biofilter Aerobik MK & & $\begin{array}{c}\mathrm{COD}_{\text {inf, }} \mathrm{TSS}_{\text {inf, }} \\
\mathrm{NH}_{4}-\mathrm{N}_{\text {inf }}\end{array}$ & $\begin{array}{c}\mathrm{COD}_{\text {ef, }} \\
\mathrm{TSS}_{\text {ef }}, \mathrm{NH}_{4}- \\
\mathrm{N}_{\text {ef }}\end{array}$ \\
\hline
\end{tabular}

Penelitian dan pemeriksaan parameter dilakukan di Laboratorium Pusat Teknologi Lingkungan-BPPT, di Gedung 820 Teknologi Sistem Kebumian (Geostech), Kawasan Puspiptek, Tangerang Selatan. Air limbah domestik berasal dari bak pengumpul di Gedung Geostech, dimana air limbah yang dikumpulkan berupa overflow dari beberapa titik tangki septik dan air limbah non-toilet. Variabel bebas pada penelitian ini yaitu waktu tinggal (hydraulic retention time, HRT); variabel terikat yaitu konsentrasi COD, TSS, NH4-N; variabel kontrol yaitu ukuran reaktor dan jenis media. Seeding dilakukan secara alami dengan HRT 48 jam. Feeding dilakukan dengan variasi HRT 24 dan 36 jam. Pemeriksaan kualitas air meliputi $\mathrm{pH}$, suhu, TSS, COD, amoniak ( $\left.\mathrm{NH}_{4}-\mathrm{N}\right)$. Analisis dilakukan terkait efisiensi removal konsentrasi parameter (COD, NH4-N, TSS) di tiap HRT berdasarkan grafik yang didapat. Selanjutnya, HRT optimum dapat ditetapkan untuk perancangan skala lapangan. Perhitungan efisiensi dan loading dilakukan dengan mengikuti persamaan (3) dan (4).

$$
E=\frac{C_{i n}-C_{e f}}{C_{\text {in }}} \times 100 \%
$$

Keterangan:

$$
\begin{aligned}
& \mathrm{E} \quad=\text { efisiensi proses pengolahan (\%); } \\
& \mathrm{C}_{\text {inf }}=\mathrm{COD}_{\text {inf }}(\mathrm{mg} / \mathrm{L}), \mathrm{NH} 4-\mathrm{N}_{\text {inf }}(\mathrm{mg} / \mathrm{L}), \mathrm{TSS}_{\text {inf }} \\
& \text { (mg/L); } \\
& \mathrm{C}_{\mathrm{ef}}=\mathrm{COD}_{\mathrm{ef}}(\mathrm{mg} / \mathrm{L}), \mathrm{NH} 4-\mathrm{N}_{\mathrm{ef}}(\mathrm{mg} / \mathrm{L}), \mathrm{TSS}_{\mathrm{ef}} \\
& \text { (mg/L). }
\end{aligned}
$$




$$
\text { Loading }=\frac{Q \times C}{V}
$$

Keterangan:

$$
\begin{aligned}
\text { Loading }= & \text { loading organik, loading amonia } \\
& \left(\text { gr/m } / \mathrm{m}^{3} \text {.hari }\right) ; \\
\text { Q } & =\text { debit air limbah }\left(\mathrm{m}^{3} / \text { hari }\right) ; \\
\mathrm{V} & =\text { COD }_{\text {inf }}\left(\mathrm{gr} / \mathrm{m}^{3}\right), \mathrm{NH}^{4}-\mathrm{N}_{\text {inf }}\left(\mathrm{gr} / \mathrm{m}^{3}\right) ; \\
\mathrm{V} & =\text { volume media }\left(\mathrm{m}^{3}\right) .
\end{aligned}
$$

\section{HASIL PENELITIAN DAN PEMBASAN}

Hasil penelitian yang didapat antara lain berupa data penurunan konsentrasi influen dan efluen. Selain itu, pengamatan visual dilakukan terhadap biofilm dan kualitas air hasil olahan. Rangkain rekator yang digunakan selama percobaan dapat dilihat pada Gambar 2.a, dan pengamatan biofilm pada akhir proses seeding dapat dilihat pada Gambar 2.b. Sedangkan pengamatan visual influen dan efluen pada akhir proses seeding dapat dilihat pada Gambar 3.

\subsection{Konsentrasi COD}

Konsentrasi COD influen selama seeding berkisar pada 337 - 510 mg/L. Berdasarkan Gambar 4, efisiensi total penurunan COD sebagai representasi penurunan senyawa organik pada tahap awal tergolong rendah yaitu 56,67 - 59,06\%. Hal ini karena pada awal seeding terjadi penyesuaian bakteri terhadap lingkungan baru sehingga dapat dikatakan pertumbuhan mikroorganisme pada reaktor belum optimal. Efisiensi total penurunan COD mencapai steady state, yakni fluktuasi $\pm 10 \%$ dan efisiensi mencapai $>80 \%$ sehingga seeding diberhentikan pada hari ke-26. Hal ini menunjukkan bahwa proses awal pertumbuhan mikroba dan pembentukan lapisan biofilm pada media membutuhkan waktu beberapa minggu, yang dikenal dengan proses pematangan (Rittmann et al., 1988; Said \& Tresnawaty, 2011).

Biofilm yang terbentuk pada lapisan atas media dinamakan zoogleal film, yang terdiri dari bakteri, fungi, alga, dan protozoa (Eighmy, 1983; Bitton, 1994; Said, 2017). Pengamatan visual biofilm di akhir seeding dapat dilihat pada Gambar 2.b. Konsentrasi TSS influen selama seeding berkisar pada 31-176 mg/L. Berdasarkan Gambar 6, efisiensi total penurunan TSS pada awal seeding tergolong rendah, yaitu 63,64$70,97 \%$. Hal ini sama seperti penurunan COD bahwa pada awal seeding mikroorganisme belum tumbuh secara optimal dan secara visual biofilm belum terlihat. Sampai akhir seeding, penurunan TSS mencapai efisiensi yang tinggi yaitu $98,3 \%$. Dapat dikatakan terjadi proses penyaringan padatan tersuspensi melalui biofilm yang terlihat semakin tebal pada akhir seeding (lihat Gambar 2.b).

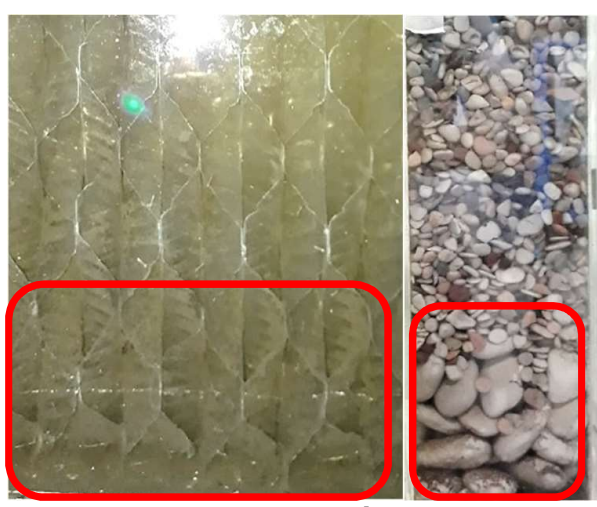

b.

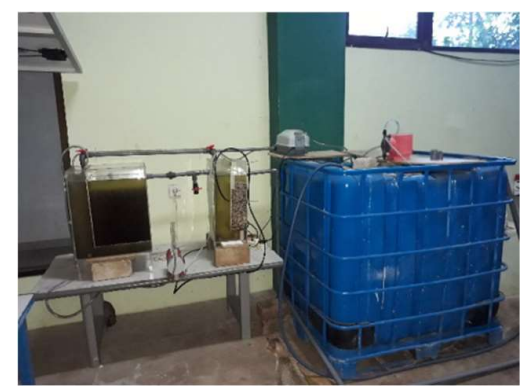

a.

Gambar 2. a. Rangkaian Reaktor Skala Laboratorium; b. Pengamatan Biofilm Akhir Seeding

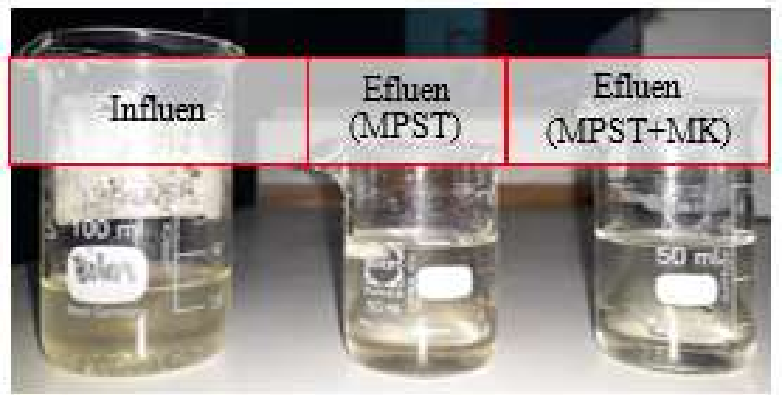

Gambar 3. Pengamatan Visual Kualitas Influen dan Efluen Akhir Feeding 


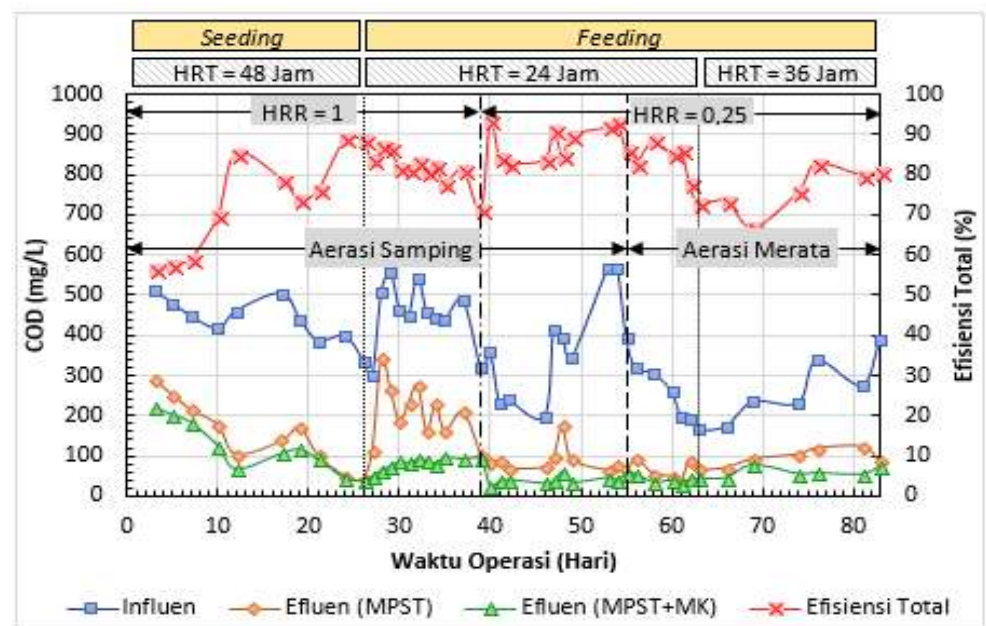

Gambar 4. Konsentrasi COD Inlet, Outlet dan Efisiensi Penghilangan.

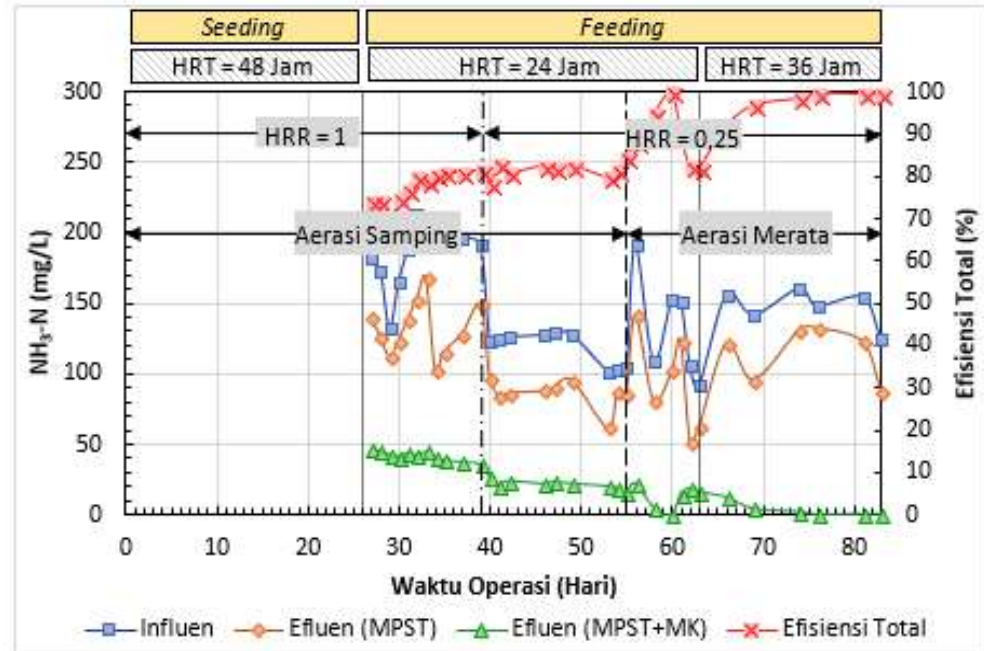

Gambar 5. Konsentrasi Amoniak( $\left.\mathrm{NH}_{4}-\mathrm{N}\right)$ Inlet, Outlet dan Efisiensi Penghilangan.

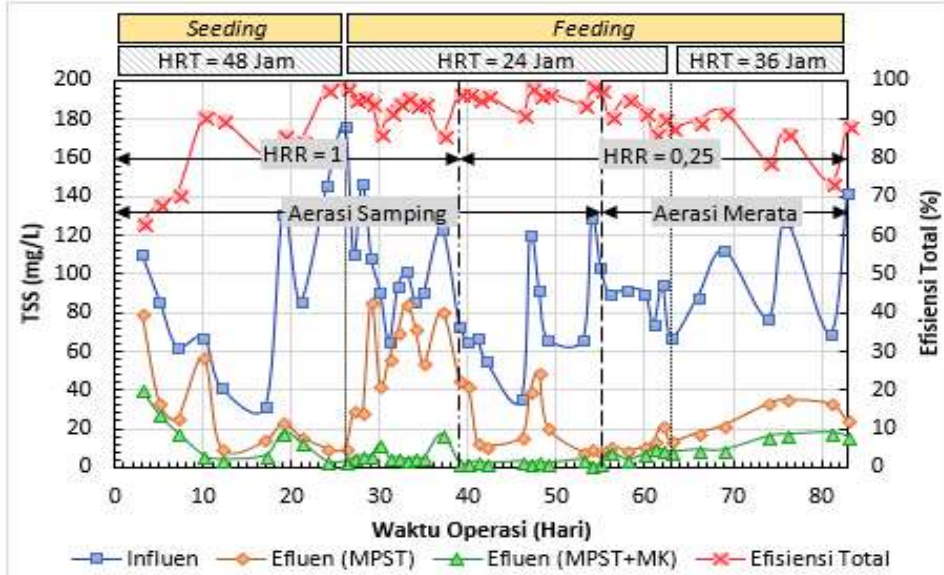

Gambar 6. Konsentrasi Total Padatan Tersuspensi (TSS) Inlet, Outlet dan Efisiensi Penghilangan.

Proses pengolahan dengan HRT 24 jam dapat menurunkan COD air limbah domestik dari $165-565 \mathrm{mg} / \mathrm{L}$ menjadi $23-96 \mathrm{mg} / \mathrm{L}$. Efisiensi total penurunan COD pada HRT 24 jam berkisar pada $71,38-93,56 \%$ (rata-rata $84,09 \%$ ). Dapat dikatakan bahwa hasil penelitian tidak jauh 
berbeda dengan hasil penelitian Ferraz et al. (2014) yang juga menggunakan SAB untuk mengolah campuran air limbah domestik dan lindi, dimana pada HRT 24 jam menghasilkan efisiensi penurunan COD sebesar $80 \%$. Untuk HRT 36 jam, COD dapat diturunkan dari 174-389 $\mathrm{mg} / \mathrm{L}$ menjadi $46-78 \mathrm{mg} / \mathrm{L}$. Efisiensi total penurunan COD pada HRT 36 jam berkisar pada $66,81-82,84 \%$ (rata-rata 76,68\%).

Berdasarkan Gambar 4, efisiensi total penurunan COD saat feeding HRT 24 jam terlihat fluktuatif. Hal ini menandakan influen yang fluktuatif berpengaruh pada efisiensi yang dihasilkan. Penurunan efisiensi terjadi karena adanya resirkulasi air olahan dengan $\operatorname{HRR} 1$, menjadikan debit air limbah yang diolah pada reaktor lebih besar. Menurut Said \& Tresnawaty (2001), semakin kecil waktu tinggal air dan debit yang diolah semakin besar menyebabkan beban pengolahan menjadi lebih besar sehingga efisiensi pengolahan mengalami penurunan. Perlakuan yang diberikan untuk mengatasi hal ini yaitu mengubah HRR dari 1 menjadi 0,25. Setelah HRR diubah, terlihat efisiensi total penurunan COD mencapai nilai tertinggi yaitu $93,56 \%$. Dapat dikatakan semakin kecil debit yang diolah menyebabkan beban pengolahan menjadi lebih kecil sehingga efisiensi pengolahan meningkat. Efisiensi mengalami fluktuasi dan semakin menurun pada akhir feeding HRT 24 jam, yakni mencapai 72,73\%. Hal ini karena adanya perubahan tipe aerasi pada hari ke-55.

Perubahan tipe aerasi dilakukan untuk meningkatkan efisiensi penurunan amoniak $\left(\mathrm{NH}_{4}-\mathrm{N}\right)$, dimana sampai hari ke-55 $\mathrm{NH}_{4}-\mathrm{N}$ efluen reaktor masih berada di atas baku mutu ( $>10$ $\mathrm{mg} / \mathrm{L})$, sementara COD efluen reaktor telah berada di bawah baku mutu ( $<100 \mathrm{mg} / \mathrm{L}$ ). Perubahan tipe aerasi dari aerasi samping menjadi aerasi merata menyebabkan adanya biofilm yang terangkat sehingga efisiensi COD menurun. Menurut Ji et al. (2014), aerasi yang berlebihan memperburuk erosi terhadap biofilm dan tidak menguntungkan bagi pertumbuhan mikro-organisme.

Pada akhir feeding, efisiensi $>80 \%$ dan telah mencapai steady state. Rata-rata efisiensi total penurunan COD pada HRT 36 jam lebih kecil dibandingkan HRT 24 jam (aerasi merata), secara berurutan $76,68 \%$ dan $82,22 \%$. Dapat dikatakan pemakaian aerasi merata dengan HRT yang lebih lama memberikan efek penurunan efisiensi COD.

\subsection{Konsentrasi Amoniak}

Rangkaian proses pengolahan dengan HRT 24 jam dapat menurunkan konsentrasi amoniak $\left(\mathrm{NH}_{4}-\mathrm{N}\right)$ air limbah domestik dari 91,82 - 212,84 $\mathrm{mg} / \mathrm{L}$ menjadi $0,25-46,86 \mathrm{mg} / \mathrm{L}$. Efisiensi total penurunan $\mathrm{NH}_{4}-\mathrm{N}$ pada HRT 24 jam berkisar pada 67,54 - 99,84\%\% (rata-rata $89,56 \%$ ). Dapat dikatakan efisiensi $\mathrm{NH}_{4}-\mathrm{N}$ pada penelitian ini lebih tinggi dibandingkan dengan efisiensi $\mathrm{NH}_{4}-\mathrm{N}$ yang dihasilkan Hibban et al. (2016) dalam penelitiannya, dimana menggunakan biofilter aerob untuk mengolah air limbah domestik, yakni pada HRT 24 jam menghasilkan efisiensi penurunan $\mathrm{NH}_{4}-\mathrm{N}$ sebesar $66,44 \%$. Untuk HRT 36 jam, NH4-N dapat diturunkan dari 123,8 - 160,29 mg/L menjadi 0,4 - 12,6 mg/L. Efisiensi total penurunan $\mathrm{NH}_{4}-\mathrm{N}$ pada HRT 36 jam berkisar pada 91,9 - 99,73\% (rata-rata $97,67 \%$ ). Berdasarkan Gambar 5, efisiensi total penurunan $\mathrm{NH}_{4}-\mathrm{N}$ di awal feeding HRT 24 jam terlihat stabil, yaitu sekitar $74 \%$. Hal ini menandakan sistem biakan melekat pada reaktor yang telah melalui tahap seeding dapat menurunkan konsentrasi $\mathrm{NH}_{4}-\mathrm{N}$ air limbah. Ketika HRR diubah, rata-rata efisiensi meningkat dari $77,23 \%$ (HRR 1) menjadi 81,7\% (HRR 0,25), kondisi aerasi samping. Dapat dikatakan HRR yang lebih kecil menjadikan beban pengolahan lebih kecil sehingga efisiensi meningkat. Agar efisiensi penurunan $\mathrm{NH}_{4}-\mathrm{N}$ lebih meningkat, dilakukan perubahan tipe aerasi dari aerasi samping menjadi aerasi merata. Hal ini mempertimbangkan $\mathrm{NH}_{4}-\mathrm{N}$ efluen yang belum memenuhi baku mutu (>10 $\mathrm{mg} / \mathrm{L})$, dimana sampai hari ke-55 konsentrasi $\mathrm{NH}_{4}-\mathrm{N}$ efluen sebesar $16,05 \mathrm{mg} / \mathrm{L}$. Pengambilan keputusan ini didukung oleh pemeriksaan konsentrasi oksigen terlarut (DO) di zona inlet dan outlet tiap reaktor, dimana pada zona outlet DO $<2 \mathrm{mg} / \mathrm{L}$ ketika dengan aerasi samping, sedangkan DO >2 mg/L ketika dengan aerasi merata. Keberadaan DO sangat penting dalam proses nitrifikasi karena proses ini berjalan secara aerobik. Proses nitrifikasi akan berjalan dengan baik jika DO minimum > 1 mg/L (Benefield \& Randall, 1980; Said, 2017), tetapi bila konsentrasi oksigen terlarut di bawah $1 \mathrm{mg} / \mathrm{L}$ maka proses nitrifikasi menjadi lambat (Metcalf \& Eddy, 1991; Said \& Tresnawaty 2001). Agar proses nitrifikasi dapat berjalan dengan baik, konsentrasi oksigen terlarut di dalam air tidak boleh kurang dari 2 mg/L (Bitton, 1994; Said, 2017). Setelah dilakukan perubahan tipe aerasi, efisiensi total penurunan $\mathrm{NH}_{4}-\mathrm{N}$ pada HRT 24 jam menjadi lebih meningkat. Efisiensi tertinggi mencapai $99,84 \%$, dimana $\mathrm{NH}_{4}-\mathrm{N}$ dapat diturunkan dari $152,53 \mathrm{mg} / \mathrm{L}$ menjadi $0,25 \mathrm{mg} / \mathrm{L}$. Efisiensi tertinggi ini terjadi karena faktor teknis berupa padamnya listrik sehingga reaktor beroperasi tanpa adanya penambahan air limbah, namun hanya air yang diresirkulasikan. Rata-rata efisiensi total penurunan $\mathrm{NH}_{4}-\mathrm{N}$ pada HRT 24 jam dengan aerasi merata lebih besar dibandingkan HRT 24 jam (HRR 0,25) dengan aerasi samping, secara berurutan $89,56 \%$ dan 
$81,7 \%$. Hal ini menunjukkan bahwa penggunaan aerasi merata menjaga kondisi oksigen terlarut pada reaktor sehingga proses nitrifikasi berjalan lebih baik. Efisiensi penurunan amoniak terus mengalami peningkatan ketika feeding dioperasikan dengan HRT 36 jam, yakni pada akhir efisiensi $>99 \%$ dan telah mencapai steady state. Rata-rata efisiensi total penurunan $\mathrm{NH}_{4}-\mathrm{N}$ dengan HRT 36 jam lebih besar dibandingkan dengan HRT 24 jam (aerasi merata), secara berurutan $97,67 \%$ dan $89,56 \%$. Hal ini sesuai dengan Said \& Tresnawaty (2001) yang mengatakan bahwa semakin lama waktu kontak antara air buangan dengan lapisan biomassa yang tumbuh di media akan semakin banyak amoniak yang terurai.

\subsection{Konsentrasi TSS}

Rangkaian proses pengolahan dengan HRT 24 jam dapat menurunkan TSS air limbah domestik dari 35-147 mg/L menjadi 1 - $17 \mathrm{mg} / \mathrm{L}$. Efisiensi total penurunan TSS pada HRT 24 jam berkisar pada 86,18 - 99,22\% (rata-rata 93,9\%). Dapat dikatakan hasil penelitian tidak jauh berbeda dengan hasil penelitian Ferraz et al. (2014) yang juga menggunakan SAB untuk mengolah campuran air limbah domestik dan lindi, dimana pada HRT 24 jam menghasilkan efisiensi penurunan TSS sebesar $90 \%$. Untuk HRT 36 jam, TSS dapat diturunkan dari 69 - 142 $\mathrm{mg} / \mathrm{L}$ menjadi $9-18 \mathrm{mg} / \mathrm{L}$. Efisiensi total penurunan TSS pada HRT 36 jam berkisar pada $73,91-91,96 \%$ (rata-rata 85,04\%). Berdasarkan Gambar 6, efisiensi total penurunan TSS pada saat feeding dengan HRT 24 jam terlihat fluktuatif. Hal ini menandakan bahwa influen yang fluktuatif berpengaruh pada efisiensi yang dihasilkan. Efisiensi total penurunan TSS pada feeding HRT 24 jam (HRR 1) sebagian besar berada di atas 90\%. Walaupun di hari ke-39 efisiensi berada pada nilai tertinggi yaitu $97,26 \%$, hidraulic recycle ratio (HRR) diubah dari 1 menjadi 0,25. Hal ini dilakukan untuk lebih meningkatkan kinerja reaktor dalam menurunkan konsentrasi COD, $\mathrm{NH}_{4}-\mathrm{N}$, dan TSS. Rata-rata efisiensi total penurunan TSS pada feeding HRT 24 jam dengan hidraulic recycle ratio (HRR) 0,25 (aerasi samping) lebih besar dibandingkan HRR 1 , secara berurutan $96,35 \%$ dan $93,43 \%$. Dapat dikatakan HRR yang lebih kecil meningkatkan kinerja reaktor dalam menurunkan konsentrasi TSS. Perubahan tipe aerasi dari aerasi samping menjadi aerasi merata menyebabkan turunnya efisiensi TSS. Rata-rata efisiensi penurunan TSS ketika feeding HRT 24 jam dengan aerasi merata lebih kecil dibandingkan dengan aerasi samping (HRR 0,25), secara berurutan 90,66\% dan $96,35 \%$. Aerasi merata menyebabkan adanya turbulensi yang mengganggu proses penyaringan padatan tersuspensi sehingga menurunkan efisiensi TSS. Rata-rata efisiensi total penurunan TSS pada HRT 36 jam lebih kecil dibandingkan HRT 24 jam (aerasi merata), secara berurutan $85,04 \%$ dan 90,66\%. Dapat dikatakan penggunaan aerasi merata dalam HRT yang lebih lama memberikan efek penurunan efisiensi TSS. Air olahan yang telah melalui kombinasi proses terlihat lebih jernih dibandingkan air olahan yang hanya melalui biofilter MPST. Hal ini menandakan kombinasi proses dapat menghasilkan air olahan yang lebih jernih (Gambar 3).

\subsection{Penetuan Waktu Tinggal Optimum}

Berdasarkan Peraturan Menteri Lingkungan Hidup dan Kehutanan Republik Indonesia Nomor: $\quad$ P.68/Menlhk/Setjen/Kum.1/8/2016 tentang Baku Mutu Air Limbah Domestik, ditetapkan kadar maksimum parameter pada air limbah domestik sebelum dibuang ke media lingkungan, di antaranya COD $100 \mathrm{mg} / \mathrm{L}$, TSS 30 $\mathrm{mg} / \mathrm{L}$, amoniak $10 \mathrm{mg} / \mathrm{L}$. Penentuan waktu tinggal optimum dipilih dengan menentukan waktu tinggal (HRT) terpendek di mana kualitas efluen sudah memenuhi baku mutu sesuai dengan Permen LHK Nomor P.68 tahun 2016. Gambar 7 menyajikan konsentrasi efluen sebagai hasil kombinasi proses yang dibandingkan dengan baku mutu. Untuk parameter COD dan TSS, terlihat telah memenuhi baku mutu pada kedua HRT yaitu COD $<100 \mathrm{mg} / \mathrm{L}$ dan TSS <30 mg/L. Parameter $\mathrm{NH}_{4}-\mathrm{N}$ terlihat sebagian besar belum dapat memenuhi baku mutu pada HRT 24 jam, sedangkan pada HRT 36 jam terlihat semakin lama dapat memenuhi baku mutu ( $<10 \mathrm{mg} / \mathrm{L}$ ) yang juga didukung oleh pemakaian aerasi merata.

Dapat dikatakan kombinasi biofilter aerobik MPST dan MK menghasilkan efluen yang memenuhi baku mutu berdasarkan waktu tinggal yang ditetapkan. HRT optimum dapat ditentukan berdasarkan baku mutu air limbah domestik acuan. Parameter COD, TSS, dapat memenuhi baku mutu untuk HRT 24 jam maupun 36 jam. Parameter $\mathrm{NH}_{4}-\mathrm{N}$ belum dapat memenuhi baku mutu pada HRT 24 jam, tetapi dapat memenuhi baku mutu pada HRT 36 jam. Jika dilihat secara keseluruhan, dengan HRT 36 jam semua parameter dapat memenuhi baku mutu air limbah domestik. HRT 36 jam yang pengoperasiannya didukung oleh aerasi merata menghasilkan kualitas efluen yang semakin bagus untuk $\mathrm{NH}_{4}$ $\mathrm{N}$, yakni dapat mencapai $<1 \mathrm{mg} / \mathrm{L}$. Jika dilihat dari efisiensinya, dalam HRT 36 jam parameter $\mathrm{NH}_{4}-\mathrm{N}$ rata-rata dapat diturunkan hingga mencapai 97,67\%. Untuk COD dan TSS, masingmasing efisiensinya rata-rata mencapai $76,68 \%$ dan $85,04 \%$. Sementara itu, parameter $\mathrm{NH}_{4}-\mathrm{N}$, COD, TSS dalam HRT 24 jam efisiensinya ratarata mencapai $89,56 \%, 82,22 \%, \quad 90,66 \%$. 
Walaupun pada HRT 24 jam semua parameter mencapai efisiensi yang tinggi, parameter $\mathrm{NH}_{4}-\mathrm{N}$ belum dapat mencapai baku mutu. HRT 36 jam ditetapkan sebagai HRT optimum dengan operasionalnya menggunakan aerasi merata sehingga semua parameter kualitas efluen (COD, NH4-N, TSS) dapat memenuhi baku mutu air limbah domestik. Dalam HRT 36 jam, efisiensi penurunan organik (COD) dapat mencapai $66,81-82,84 \%$ dengan beban organik 0,12-0,27 $\mathrm{kg} / \mathrm{m}^{3}$.hari. Untuk amoniak $\left(\mathrm{NH}_{4}-\mathrm{N}\right)$, efisiensi dapat mencapai 91,9-99,73\% dengan beban amoniak 0,08-0,11 kg/m³.hari.

Dari penelitian yang telah dilakukan, didapat kriteria desain yang dapat digunakan untuk merancang IPAL domestik. Kriteria desain yang dihasilkan antara lain HRT dan efisiensi penurunan konsentrasi polutan air limbah (COD, $\mathrm{NH}_{4}-\mathrm{N}$, TSS) untuk untuk sistem biofilter aerobik. Data lain yang dibutuhkan untuk merancang biofilter MPST maupun biofilter MK yaitu rasio volume media/volume total reaktor yang digunakan pada penelitian ini. Konsep umum pengolahan air limbah domestik individual yang dirancang berdasarkan penelitian yang dilakukan dengan penambahan bak pengendapan awal dan akhir, yang mempertimbangkan kondisi asli di lapangan.

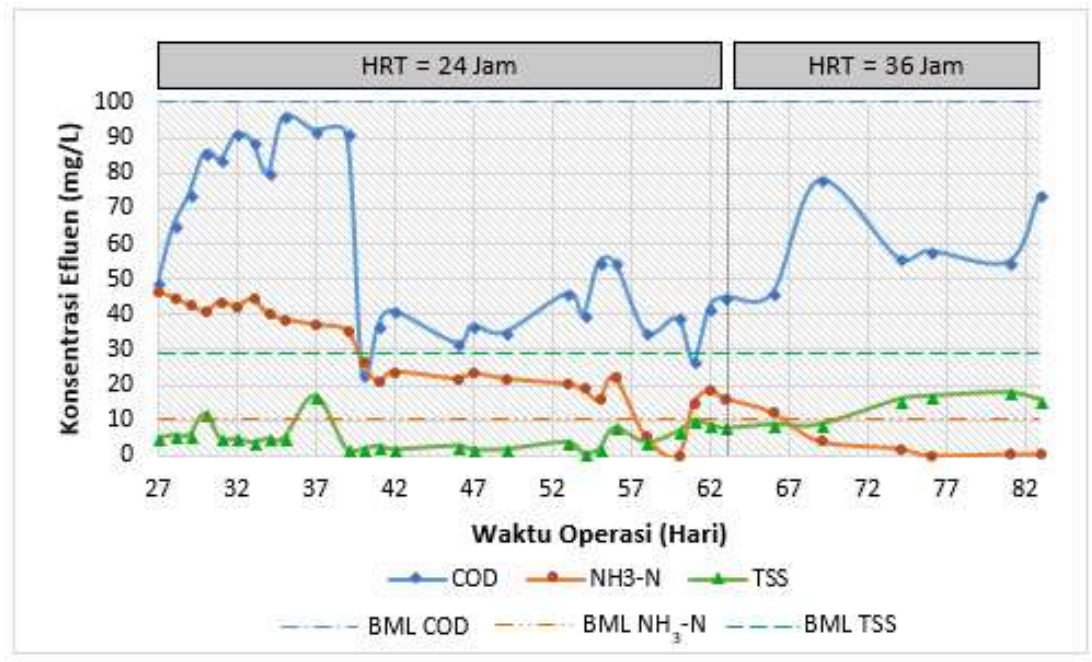

Gambar 7. Konsentrasi Efluen terhadap Baku Mutu Lingkungan

\section{KESIMPULAN}

Kombinasi biofilter aerobik MPST dan biofilter MK dengan HRT 24 jam menurunkan konsentrasi COD, $\mathrm{NH}_{4}-\mathrm{N}$, TSS air limbah domestik masing-masing 71,38 - 93,56\% (ratarata $84,09 \%$ ), $67,54-99,84 \%$ (rata-rata $81,62 \%$ ), 86,18 - 99,22\% (rata-rata 93,9\%). Dengan HRT 36 jam dapat menurunkan konsentrasi COD, $\mathrm{NH}_{4}-\mathrm{N}$, TSS masing-masing 66,81 - 82,84\% (rata-rata 76,68\%), 91,9 - 99,73\% (rata-rata $97,67 \%$ ), 73,91 - 91,96\% (rata-rata 85,04\%). Efisiensi penurunan selain dipengaruhi variasi HRT, juga dipengaruhi perlakuan yang harus diberikan pada feeding HRT 24 jam untuk meningkatkan kinerja reaktor yaitu berupa perubahan HRR dan tipe aerasi. Perubahan HRR dari 1 ke 0,25 (aerasi samping) meningkatkan kinerja reaktor dalam menurunkan COD dari $81,5 \%$ menjadi $88,05 \%, \quad \mathrm{NH}_{4}-\mathrm{N}$ dari $77,23 \%$ menjadi $81,7 \%$, TSS dari $93,43 \%$ menjadi 96,35\%. Perubahan tipe aerasi dari aerasi samping menjadi aerasi merata dengan HRR 0,25 meningkatkan kinerja reaktor dalam menurunkan $\mathrm{NH}_{4}-\mathrm{N}$ dari $81,7 \%$ menjadi $89,56 \%$, sementara COD turun dari $88,05 \%$ menjadi $82,22 \%$ dan TSS turun dari $96,35 \%$ menjadi $90,66 \%$.

Dapat dilihat bahwa efisiensi penurunan konsentrasi $\mathrm{NH}_{4}-\mathrm{N}$ dapat mencapai nilai yang sangat tinggi dan stabil ketika menggunakan aerasi merata dan dengan HRT yang lebih lama. Penerapan teknologi kombinasi ini dilakukan untuk merancang IPAL skala lapangan. Dari hasil penelitian di dapatkan total waktu tinggal optimum di dalam sistem biofilter adalah 36 jam.

\section{Saran}

Sebaiknya, HRR ditetapkan berdasarkan kapasitas pompa sirkulasi dan nilainya lebih kecil daripada debit air limbah yang masuk ke reaktor sehingga kinerja reaktor tidak menurun. Selain itu, mempertimbangkan tipe aerasi yang digunakan. Aerasi samping tidak menyebabkan turbulensi yang berpengaruh pada turunnya efisiensi COD dan TSS, sementara aerasi merata dapat meningkatkan efisiensi $\mathrm{NH}_{4}-\mathrm{N}$ menjadi 
sangat tinggi. Blower yang digunakan juga disesuaikan kapasitasnya sesuai kondisi air limbah yang diolah. Pemeriksaan parameter bakteri Nitrosomonas dan Nitrobacter dapat dilakukan untuk memastikan terjadi proses nitrifikasi dalam reaktor, serta parameter total coliform pada efluen reaktor sebagai parameter lain yang diatur kadar maksimumnya pada baku mutu air limbah domestik acuan.

\section{PERSANTUNAN}

Penulis menyampaikan terima kasih kepada Direktur Pusat Teknologi Lingkungan atas bantuan dan fasilitasinya dalam melakukan kajian penelitian ini. Terimakasih juga disampaikan kepada Ir. Wahyu Widayat, Msi. dan Imam Setiadi, ST. yang telah mendukung terlaksananya kegiatan ini.

\section{DAFTAR PUSTAKA}

1. Benefield, L.D., \& Randall, C.W. (1980). Biological Process Design for Wastewater Treatment. Englewood Cliffs, NJ: PrenticeHall.

2. Bitton, G. (1994). Wastewater Microbiology. New York: Wiley-Liss.

3. Boller, M. (1993). Filter mechanism in roughing filters. Water SRT-Aqua, 42 (3), 174-185.

4. Eighmy, T.T., Maratea, D., Bishop, P.L. (1983). Electron Microscopic Examination of Wastewater Biofilm Formation and Structural Components. Applied and Environmental Microbiology, June 1983, Vol. 45, No. 6, p. 1921-1931.

5. Ferraz, F.M., Povinelli, J., Pozzi, E., Vieira, E.M., Trofino, J.C. (2014). Co-treatment of landfill leachate and domestic wastewater using a submerged aerobic biofilter. Journal of Environmental Management, 141 (2014) 9-15.

6. Gálvez, a, Giusti, L., Zamorano, M., RamosRidao, A.F. (2009). Stability and efficiency of biofilms for landfill leachate treatment. Bioresour. Technol. 100, 4895-4898.

7. Galvis, G. (1999). Development and Evaluation of Multistage Filtration Plants: An Innovative, Robust and Efficient Water Treatment Technology. PhD Thesis, CEHE, University of Surrey, Guildford, Survey, UK, p. 228.

8. Hait, S., Mazumder, D. (2009). Performance evaluation of aerobic biofilter with high organics containing synthetic wastewater. Int. J. Environment and Pollution, Vol. 37, Nos. 2/3, 2009.

9. Hibban, M., Rezagama, A., Purwono. (2016). Studi Penurunan Konsentrasi Amonia dalam Limbah Cair Domestik dengan Teknologi Biofilter Aerob Media Tubular Plastik pada Awal Pengolahan. Jurnal Teknik Lingkungan, Vol. 5, No.2 (2016). Metcalf \& Eddy. (1991). Wastewater Engineering: Treatment, Disposal, and Reuse, Third Edition. New York: McGrawHill.

10. Ji, B., Wang, H., Yang, K. (2014). Nitrate and COD removal in an upflow biofilter under an aerobic atmosphere. Bioresource Technology, 158 (2014) 156-160.

11. Kim, Y., Tanaka, K., Lee, Y., Chung, J. (2008). Development and application of kinetic model on biological anoxic/aerobic filter. Chemosphere, 70, 990-1001.

12. Leenen, E., DosSantos, V.A.P., Grolle, K.C.F., Tramper, J., Wijffels, R.H. (1996). Characteristics of and selection criteria for support materials for cell immobilization in wastewater treatment. Water Res., 12: 2985-2996.

13. Martins, S.C.S., Martins, C.M., Fiuza, L.M.C.G., Santaella, S.T. (2013). Immobilization of microbial cells: A promising tool for treatment of toxic pollutants in industrial wastewater. African Journal of Biotechnology, Vol. 12(28), pp. 4412-4418, 10 July, 2013.

14. Maryland Department of The Environment. (2016). Design Guidelines for Wastewater Facilities. Baltimore, MD: Author.

15. Metcalf \& Eddy. (2003). Wastewater Engineering: Treatment and Reuse (4th int. ed.). New York: McGraw-Hill.

16. Mishra, T., Ramola, S., Shankhwar A.K., Rabha, A.K., Srivastava, R.K. (2015). Pulp and paper mill effluent treatment by hybrid anaerobic upflow fixed-bed bioreactor combined with slow sand filter. Desalination and Water Treatment, DOI: 10.1080/19443994.2015.1039596.

17. Newton, C., Wilson, J.P. (2008). Recirculating gravel filters: highperformance treatment at low cost for two small communities. Water Science \& Technology, 58.6, 2008.

18. Rittmann, B.E., Jackson, D., Storck, S.L. (1988). Potential for treatment of hazardous organic chemicals with biological processes. In. D. L. Wise (Ed.). Biotreatment Systems (vol. 3, pp. 15-64). Boca Raton, FL: CRC Press.

19. Sánchez, L.D., Visscher, J.T., Rietveld, L.C. (2015). Performance of upflow gravel filtration in multi-stage filtration plants. Water Science \& Technology, 71.4, 2015.

20. Said, N.I. (2005). Penggunaan Media Serat Plastik pada Proses Biofilter Tercelup untuk Pengolahan Air Limbah Rumah Tangga Non Toilet. JA/ Vol.1, No. 2, 2005. 
21. Said, N.I. (2008). Pengolahan Air Limbah Domestik di DKI Jakarta: "Tinjauan Permasalahan, Strategi dan Teknologi Pengolahan". Jakarta: Pusat Teknologi Lingkungan, Deputi Bidang Teknologi Pengembangan Sumberdaya Alam, Badan Pengkajian dan Penerapan Teknologi.

22. Said, N.I. (2017). Teknologi Pengolahan Air Limbah: Teori dan Aplikasi. Jakarta: Penerbit Erlangga.

23. Said, N.I., Hartaja, D.R.K. (2015). Pengolahan Air Lindi dengan Proses Biofilter Anaerob-Aerob dan Denitrifikasi. JAI, Vol. 8, No. 1, 2015.

24. Said, N.I., Ruliasih. (2005). Tinjauan Aspek Teknis Pemilihan Media Biofilter untuk Pengolahan Air Limbah. JAI, Vol. 1, No. 3, 2005.
25. Said, N.I., Tresnawaty, R. (2001). Penghilangan amoniak di dalam air baku air minum dengan proses biofilter tercelup menggunakan media plastik sarang tawon. Jurnal Teknologi Lingkungan, Vol. 2, No. 1, Januari 2001: 11-27.

26. Zacheus, O.M., Livanainen, E.K., Nissinen, T.K., Lehtola, M.J., Martikainen, P.J. (2000). Bacterial biofilm formation on polyvinyl chloride, polyethylene and stainless steel exposed to ozonated water. Water Res., 34:63-70.

27. Zahra, L.Z., Purwanti, I.F. (2015). Pengolahan Limbah Rumah Makan dengan Proses Biofilter Aerobik.JURNAL TEKNIK ITS, Vol. 4, No.1, ISSN: 2337-3539. 